\title{
Oczopląs - Zart czy objaw patologiczny (opis przypadku pacjentki z oczopląsem umyślnym)
}

\section{Nystagmus - eye joke or pathological sign (case of voluntary nystagmus).}

\author{
Marta Zawadzka (D), Jakub Szymarek (D), Agnieszka Matheisel (D), Anna Lemska (D), \\ Sandra Modrzejewska (D), Ewelina Trybała (D), Maria Mazurkiewicz-Bełdzińska (D) \\ Klinika Neurologii Rozwojowej, Gdański Uniwersytet Medyczny
}

DOI:10.20966/chn.2019.56.442

\section{STRESZCZENIE}

Oczopląs umyślny (ang. voluntary nystagmus) to wahadłowe, szybkie, poziome oscylacje gałek ocznych, bez fazy wolnej, inicjowane i utrzymywane przez pacjenta świadomie. Czas trwania tych oscylacji jest ograniczony zmęczeniem pacjenta. Przedstawiamy przypadek 13-letniejdziewczynki z oczopląsem, silnym bólem głowy i nudnościami. Podczas badania neurologicznego, w trakcie fiksacji stwierdzono oczopląs poziomy, dziewczyna skarżyła się również na zaburzenia widzenia pod postacią zamazanego obrazu. W badaniach dodatkowych (badanie okulistyczne, rezonans magnetyczny mózgowia) nie stwierdzono nieprawidłowości. Dokładna obserwacja pacjentki udowodniła, że dziewczynka świadomie demonstruje oczopląs.Umyślny oczopląs należy rozważyć w każdym przypadku, w którym zdiagnozowano przerywany, izolowany oczopląs, szczególnie w sytuacji gdy nie stwierdzono zmian okulistycznych lub innych objawów neurologicznych.

Słowa kluczowe: zaburzenia gałkoruchowe, dobrowolny oczopląs, nastolatek
ABSTRACT

Voluntary nystagmus is a pendular, rapid, primarily horizontal oscillation of the eyes, without a slow phase, often initiated and maintained by voluntary effort, its duration limited by fatigue. We present a case of 13-year old girl with nystagmus, severe headache and nausea. On examination the subject's eyes moved normally, but during fixation at near point horizontal nystagmus was observed and the girl complained about blurred vision. Otherwise, opthalmological examination and brain MRI revealed no abnormalities. Close observation of the girl proved that she can produce nystagmus voluntarily. Voluntary nystagmus should be considered in every individual case of patients diagnosed with isolated, intermittent nystagmus, especially of those without ophthalmologically or neurologically pathologic findings.

Keywords: eye movement disorders, voluntary nystagmus, adolescent

\section{INTRODUCTION}

Nystagmus is an involuntary oscillation of one or both eyes in one or more axes. It is characterized by the planes of the oscillation, directions of gaze at which nystagmus is present, degree of conjugacy, its amplitude and frequency [1]. By definition, nystagmus must have a slow and fast phase [2]. It can be congenital, acquired or physiological, with variations within each type $[1,3]$. Pathological nystagmus is due to a disorder of any of three mechanisms regulating movement and position of the eyes: vestibular mechanism, fixation or conjugate gaze. It results from a peripheral vestibular lesion or can indicate the brain stem or cerebellum lesions [3]. Lifelong, congenital nystagmus is usually horizontal, rarely pendular and generally is characterized by a high fixation dependendance. Typically, it has a high frequency and variable waveform. This form of nystagmus is divided into the most common afferent nystagmus (due to vision problems) and the rarely seen efferent nystagmus (due to ocular motor disturbance) [4]. The physiological nystagmus may be induced by some specific stimuli such as self-rotation or extreme horizontal and upward gaze (e.g. optokinetic, vestibular and end-point nystagmus) [1].

\section{CASE STUDY}

A 13-year-old girl was admitted to the Department of Developmental Neurology with a case of headache persisting for several days. She complained about severe diffused headaches with nausea, without vomiting. The patient was in good health previously, the psychomotor development was normal. On examination the subject's eyes moved normally, but during fixation at near point horizontal nystagmus was observed and the girl complained about blurred vision. During the evaluation of patient's eye movement she did not want to cooperate longer than about 30 seconds. After this period she closed the eyes or looked away. She explained that she was tired of looking. Full clinical assessment, ophthalmological examination and brain MRI revealed no abnormalities. Apart from nystagmus there were no other objective neurological signs. In the course of hospitalization she did not complain about headache but she behaved immaturely and wanted to attract our attention.

Psychological evaluation revealed emotional immaturity and instability, a tendency to seek attention, various psychosomatic complaints that may also contribute in oph- 
thalmic symptoms. Under surveillance conducted without her knowledge, nystagmus was not observed. The patient admitted that she was able to wobble her eyes voluntarily. She also said that while being examined by her doctor she was not able to abstain from joking with her eyes.

\section{DISCUSSION}

Psychogenic eye movement disorders are less established in medical literature than other functional disorders but they are not very rare. In addition to voluntary nystagmus, psychogenic eye movement disorders also include functional convergence spasms, convergence paralysis, functional gaze limitation, tonic gaze deviation or functional opsoclonus. The characteristic features of all psychogenic eye movement disorders are abrupt onset, fluctuation of symptoms and their disappearance with distraction. We can also observe improvement with suggestion or placebo [5].

Voluntary nystagmus has been described in the literature since the mid $19^{\text {th }}$ century. It is also known as voluntary ocular tremor, voluntary ocular flutter or functional ocular oscillation $[6,7]$.

It is a pendular, rapid, primarily horizontal oscillation of the eyes, without a slow phase, often initiated and maintained by voluntary effort [5,8-10]. The frequency of the voluntary nystagmus is high, approximately about $10 \mathrm{~Hz}$ and the mean amplitude approximately 4 degrees $[5,11]$. Most patients discover their ability for voluntary nystagmus in childhood, especially between age 8 to 15 . The voluntary nystagmus can be initiated independently of eye position or fixation. It can appear even with the eyes closed or in darkness [7]. The duration of voluntary nystagmus is brief - up to 20 seconds [5]. It is usually reduced by fatigue and this relationship is almost always pathognomonic [9].

Just as in our case, voluntary nystagmus has been described in literature as a trick, which can cause some confusion during routine neurological or ophthalmological examination [7]. Bassini described the case of a woman who developed this ability in drama class and used it in her work on stage [11]. In another case, soldiers used this skill hoping to obtain compensation or discharge from the army [6]. This phenomenon was also described with other functional disorders such as head tremor and bowel disorders $[6,12]$.
However, it should not be forgotten that transient eye oscillopsia may also be pathological. Differential diagnosis for intermittent eye oscillopsia is vestibular paroxysmia, superior oblique myokymia (spasmodic contraction of oblique muscle) and opsoclonus [5].

The prevalence of voluntary nystagmus is quite high. It was estimated to be $5 \%$ in population of several hundred undergraduates [6]. Zahn found that $8 \%$ of a college age population could produce it [7]. A higher prevalence of ability to present voluntary nystagmus was detected between hearing-impaired students. It was reported by Aschoff to be $11 \%$ [13].

In some cases voluntary nystagmus has a familial component, it can also be learnt $[6,8,9,14]$.

In order to reduce the possibility of misdiagnosis, voluntary nystagmus should be considered in every individual case of patients diagnosed with it in relation to isolated, intermittent nystagmus and associated psychological abnormalities [8].

\section{REFERENCES:}

[1] Abadi R.V.: Mechanisms underlying nystagmus. J R Soc Med. 2002; 95: 231-234.

[2] Quiros P.A, Yee R.D.: Nystagmus, Saccadic Intrusions, and Oscillations. Ophthalmology. Elsevier 2014.

[3] Olitsky S.E., Hug D., Plummer L.S., et al.: Disorders of Eye Movement and Alignment. Nelson Textbook of Pediatrics. Elsevier 2016.

[4] Baloh R.W., Jen J.C.: Neuro-Ophthalmology. Goldman-Cecil Medicine, Elsevier 2016.

[5] Aminoff M.J., Boller F., Swaab D.F.: Handbook of Clinical Neurology. Functional Neurologic Disorders. Elsevier 2016.

[6] Neppert B, Rambold H.: Familial voluntary nystagmus. Strabismus 2006; 14: 115-119.

[7] Zahn J.R.: Incidence and characteristics of voluntary nystagmus. Journal of Neurology, Neurosurgery and Psychiatry 1978; 41: 617-623.

[8] Jarrett A., Emery J.M., Coats A.C., et al.: Voluntary nystagmus. Ann Opthalmol. 1977; 9: 853-859.

[9] Lee A.G., Brazis P.W.: Clinical pathways in neuro-opthalmology: An evidence-based approach. $2^{\text {nd }}$ edition. Theme Medical Publishers, Stuttgart 2003.

[10] Miller N.R., Newman N.J., Biousse V., et al.: Walsh and Hoyt's clinical neuro-opthalmology: the essentials. Lippincott Williams\&Wilkins, Philadelphia 2008.

[11] Bassani R.: Images in clinical medicine. Voluntary nystagmus. N Eng J Med 2012; 367: 13.

[12] Lee J., Gresty M.: A case of "voluntary nystagmus" and head tremor. Journal of Neurology, Neurosurgery and Psychiatry 1993; 56: 13211322.

[13] Aschoff J.C., Bechinger D., Conrad B.: Voluntary nystagmus in deaf mutes. Nervenartzt 1976; 47: 435-438.

[14] Hotson J.R.: Convergence-initiated voluntary flutter: a normal intrinsic capability in man. Brain Res. 1984; 294: 299-304. 